\title{
Reducing production of taste and odor by deep-living cyanobacteria in drinking water reservoirs by regulation of water level
}

\author{
Ming Su ${ }^{a}$, Dongmin Jia ${ }^{b}$, Jianwei Yu ${ }^{a}$, Rolf D. Vogt ${ }^{c}$, Jingshi Wang ${ }^{b}$, Wei An ${ }^{a, *}$, Min Yang ${ }^{a, *}$

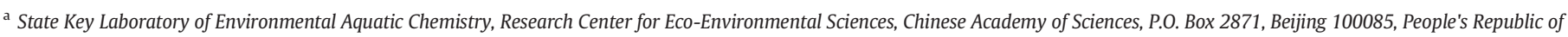 \\ China \\ b Miyun Reservoir Administration, Xiwenzhuang, Miyun, Beijing 101512, People's Republic of China \\ c Department of Chemistry, University of Oslo. P.O. Box 1033, Oslo 0315, Norway
}

\section{H I G H L I G H T}

- Water level regulation is a feasible abatement action to control cyanobacterial.

- The optimized water level differs for different types of reservoirs.

- The risk of suffering T\&O problems can be reduced by regulating water level.
GRA PH ICA L A B STRACT

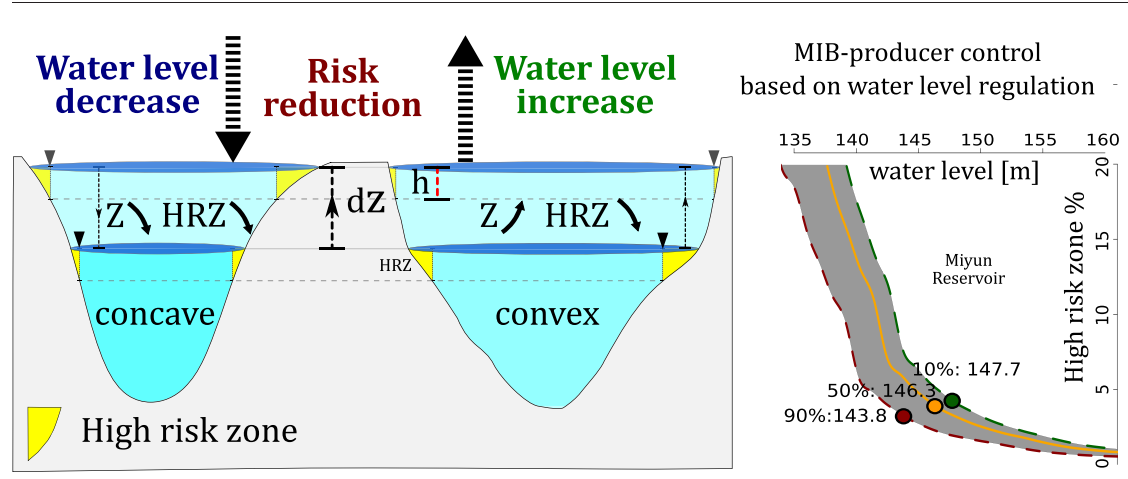

\section{A R T I C L E I N F O}

\section{Article history:}

Received 26 May 2016

Received in revised form 13 August 2016

Accepted 19 August 2016

Available online 1 October 2016

Editor: D. Barcelo

\section{Keywords:}

Planktothrix

2-Methylisoborneol

Taste and odor

Drinking water

Control

\begin{abstract}
A B S T R A C T
Abatement and control of algae, producing toxins and creating taste \& odor (T\&O) in drinking water sources, is a major challenge for water supply. In this study we proposed a strategy based on water level regulation for the control of odor-producing cyanobacteria in source water. Miyun Reservoir, the main surface water source for Beijing, has been suffering from 2-methylisoborneol (2-MIB) induced T\&O problems caused by deep-living Planktothrix sp. since 2002. The biomass of deep-living Planktothrix in Miyun Reservoir was found to be mainly governed by the water depth above its sediment habitat. An algorithm for water level regulation aiming to minimize the risk for $T \& O$ in different types of reservoirs is proposed.

The study demonstrates that risk for T\&O can be minimized by increasing the water level in Miyun Reservoir. The high-risk area can be reduced by about $2.91 \%$ ( $0.61 \%$ to $5.76 \%$ ) of surface area for each meter increase in the water level, when the water level is lower than $145 \mathrm{~m}$. More specifically, the water level needs to be raised to higher than $147.7 \mathrm{~m}$ a.s.l. from $131.0 \mathrm{~m}$ in order to obtain an acceptable risk level (ARL) of 10\%. This management strategy to abate $T \& O$ problems is simpler and cheaper to implement compared to traditional physical, chemical and biological techniques. Moreover, it has no apparent negative impact on water quality and aquatic organisms.
\end{abstract}

(c) 2016 Published by Elsevier B.V.

\footnotetext{
* Corresponding authors.

E-mail addresses: mingsu@rcees.ac.cn (M. Su), anwei@rcees.ac.cn (W. An), yangmin@rcees.ac.cn (M. Yang).
} 


\section{Introduction}

Complaints from consumers regarding the foul flavor of drinking water has become one of the major problems facing waterworks (Westerhoff et al., 2005; Izaguirre and Taylor, 2007; Yang et al., 2008). 2-methylisoborneol (2-MIB) is generally considered to be the main compounds responsible for the poor flavor. The major 2-MIB producers have been identified as the benthic and deep-living cyanobacteria: Oscillatoria sp., Phormidium sp., Pseudanabaena sp. and Planktothrix sp. (Izaguirre, 1992; Izaguirre and Taylor, 1998; Sugiura et al., 1998; AWWA, 2010; Su et al., 2015). It is therefore necessary for waterworks to prevent blooming of these odor-producing cyanobacteria in their source waters. These species are able to obtain nutrients from sediment surfaces or deep water layers where the nutrients' concentration are usually higher (Dokulil and Teubner, 2012; Su et al., 2015). They thereby are also able to bloom in oligotrophic drinking water resources. However, little has been done so far in terms of the control of these organisms.

Underwater light availability can be regarded as one of the important limiting resources governing the growth of deep-living cyanobacteria (Reynolds, 2006; Scott and Marcarelli, 2012; Su et al., 2014). Thus, reducing the underwater light intensity to limit these deep-living organisms can potentially be an effective measure to control and/or prevent their growth. This can be achieved by adjusting the water depth in the reservoirs during their blooming season, since water depth (distance between water surface and the layer where cells stay) is one of the two most important factors governing the underwater light intensity, together with water extinction efficiency determined mainly by water transparency. Water level operation in reservoirs has been widely used for flood control (Plate, 2002), water storage (Kurek and Ostfeld, 2013) as well as saltwater intrusion prevention. However, no application of this method for control of deep-living cyanobacteria has been reported so far.

Compared to traditional measures to reduce and control harmful algal blooms (HABs) in reservoirs, including physical, chemical and biological control techniques, water level adjustment has several advantages: 1 . No negative impact on water quality since no additional chemical inputs are required; 2 . Low power input compared to physical controls including hydrological manipulation and hypolimnetic aeration; 3. Less complexity to operate compared to bio-manipulation etc. (Everall and Lees, 1997; Peretyatko et al., 2012). Moreover, the fact that MIB-producing cyanobacteria usually grow on the sediment surface (Dokulil and Teubner, 2012; Su et al., 2015) further restricts those traditional options.

This study explores a possible novel strategy based on water level regulation to reduce the underwater light availability, thereby to prevent the blooming of MIB-producing cyanobacteria. Based on a fouryear investigation and a focused study in a drinking water reservoir, the effect of water level regulation on the control of odor-producing Planktothrix sp. has been clarified, and an algorithm aiming to minimize the bloom risk based on water level regulation for different types of reservoirs has been developed. This study thereby presents a science based management tool to control T\&O problems in drinking water, ensuring a sustainable use of our raw water resources.

\section{Methods}

\subsection{Study area}

A general description of Miyun Reservoir can be found in the preceding study of Su et al. (2015) (Section 2.1 Study area). The bathymetry of this reservoir is central to this study and is shown in Fig. A.4. This map was generated by interpolating depth data collected from an Acoustic Doppler Current Profiler instrument (ADCP, LAUREL, USA). The full reservoir level (FRL) is $157.5 \mathrm{~m}$ a.s.l., corresponding to a water holding capacity of $3.954 \mathrm{~km}^{3}$ and surface area of $179.33 \mathrm{~km}^{2}$; the spillway crest level (SCL) is at $147.0 \mathrm{~m}$, corresponding to $2.294 \mathrm{~km}^{3}$ volume and $137.54 \mathrm{~km}^{2}$ surface area; the dead storage of this reservoir is approximately $0.4190 \mathrm{~km}^{3}$ at $126.0 \mathrm{~m}$ (DSL) with a surface area of 46.150 $\mathrm{km}^{2}$. However, the Miyun Reservoir has never been full. A maximum storage of $3.170 \mathrm{~km}^{3}(152.8 \mathrm{~m})$ was recorded in 1975 . Due to continuous drought and over extraction the amount of water has decreased to between $0.84 \mathrm{~km}^{3}$ and $1.26 \mathrm{~km}^{3}$ over the last four years, corresponding to $133.1 \mathrm{~m}$ and $138.1 \mathrm{~m}$ in water level, respectively. This is equivalent to only one fourth of the total water storage capacity, as shown in Fig. 1.

Miyun Reservoir has received the water from Danjiangkou Reservoir through SNWD Project. This canal will initially provide $9.5 \mathrm{~km}^{3}$ of water annually, and this is expected to increase to $13.0 \mathrm{~km}^{3}$ annually by 2030 (Anonymous, 2014), although in dry years the annual transferred amount will be less (at least $6.2 \mathrm{~km}^{3}$, with a 95\% guarantee rate) (SNWDP, C. o. t. S. C., 2014). This implies that the amount of water stored in the Miyun Reservoir will probably increase in the coming years.

\subsection{Sampling}

The samples for pre-study (Su et al., 2015) were collected from different regions of Miyun Reservoir between 2009 and 2012. In the prestudy seventeen sites were sampled in the shallow region of Miyun Reservoir, comprising the major habitat for the MIB-producing cyanobacteria. Sampling locations were located with a GPS navigator (Garmin, Olathe, KS, USA) and actual water depth at the location during the sampling recorded using a sonar-based depth meter (Amron AMRDS-1, USA). In order to further identify the effect of water depth on growth of Planktothrix sp., a specific investigation was performed during the main blooming season for the odor-producing cyanobacteria in September 2012 (Su et al., 2015) in the shallow region of Miyun Reservoir. The sampling time and region were selected according to the seasonal and spatial distribution pattern of Planktothrix biomass and 2-MIB concentration, hence capturing the essential information and excluding other confounding factors. A total of 27 valid water samples were collected from the bottom layer close to the sediment surface.

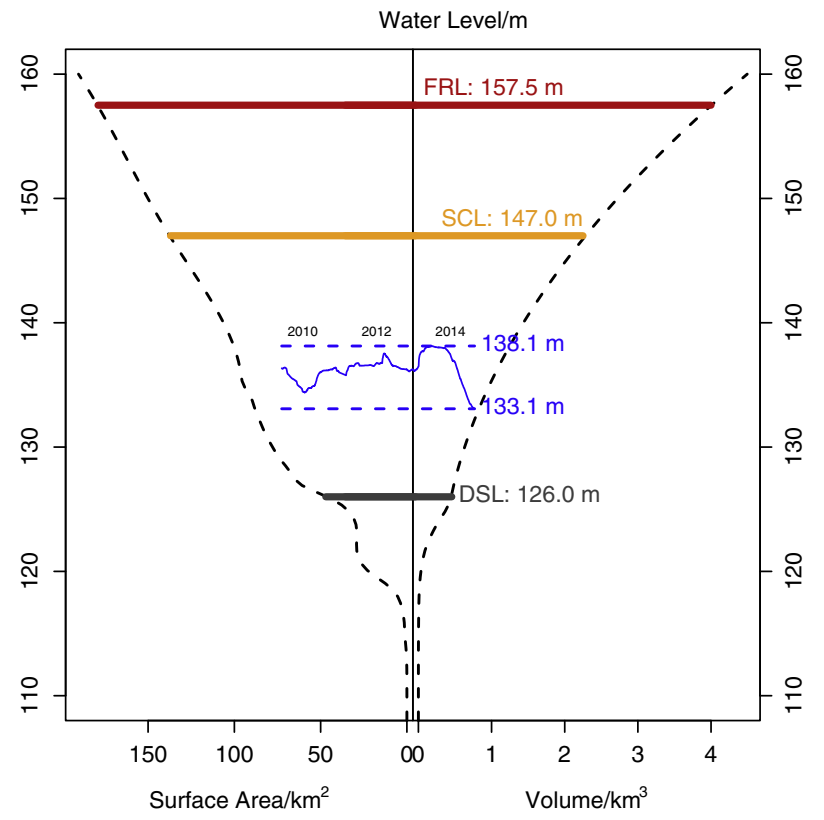

Fig. 1. The elevation-surface area/volume curve of Miyun Reservoir. The dashed curves denote the elevation-surface area (left) and elevation-volume (right) relations of Miyun Reservoir; the gray line denotes the dead storage level (DSL); the yellow line denotes the spillway crest level (SCL), and the red one denotes the full reservoir level (FRL); the blue curve denotes the water level fluctuation of Miyun Reservoir during 2010 to 2014. 


\subsection{Algal enumeration}

Samples $(100 \mathrm{~mL})$ for cell enumeration were preserved with $5 \%$ Lugol's iodine (Sherr and Sherr, 1993) and stored $48 \mathrm{~h}$ for static settling. Subsequently the algal cells were up-concentrated by a factor of ten by carefully decanting off $90 \mathrm{~mL}$ of the supernatant. The remaining tenfold concentrate was stored in the dark until cell counting was performed. The cell density was determined by the Utermöhl technique using a Sedgewick-Rafter counting chamber under a microscope (Olympus BX51) with phase contrast and bright field illumination (Hasle, 1978). The taxonomy of algal species was determined at $320 \times$ and $480 \times$ magnifications following (Bellinger, 1974; Prescott, 1951; Komárek and Anagnostidis, 1998; Ling and Tyler, 2000). The identification of MIBproducing Planktothrix was performed according to the shape and size of its filaments as well as their growth characteristics. The numbers of cells were counted at $160 \times$ magnification of $1 \mathrm{~mL}$ concentrated samples in separately sampled triplicate measurements. Since the genus Planktothrix sp. is a filamentous alga, the cell densities were determined by measuring the length of each filament and dividing the total filament length in a sample by the cell length. The average cell length was determined by dividing the measured total length of 50 filaments in a mixed sample by the counted number of cells.

\subsection{Reservoir elevation}

The Advanced Spaceborne Thermal Emission and Reflection Radiometer Global Digital Elevation Model (ASTER GDEM V2) was used to establish the elevation of the water level in the reservoir. The data are available on a 1 arc-second (approximately $30 \mathrm{~m}$ at the equator) grid and referenced to the 1984 World Geodetic System (WGS84) and 1996 Earth Gravitational Model (EGM96) geoid. The ASTER GDEM data was downloaded from the NASA-USGS LP DAAC web page. In this paper, the geo-locations of 40; $\mathrm{N}$ and 116; E to 117; E were used. This offers a spatial resolution of $30 \mathrm{~m}$ and an RMSE $\mathrm{xyz}_{\mathrm{xyz}}$ of better than $25 \mathrm{~m}$ (DAAC, 2014). The water surface of Miyun Reservoir was determined to be $127 \mathrm{~m}$ a.s.l.

\subsection{Defining area of high risk}

The surface area of the reservoir's high-risk zone, defined as the region with a water depth less than a certain value $(h)$, was calculated according to Eq. (1).

$A_{r}=A_{z_{0}}-A_{z_{1}}$

Where $A_{r}$ denotes the surface area of the high-risk zone (Fig. A.1), $A_{z_{0}}$ is the total water surface area when water level is $z_{0}$, and $A_{z_{1}}$ is the surface area when water level is $z_{1}$, which is lower than $z_{0}$ for $h\left(h=z_{0}-\right.$ $z_{1}$ ). ArcGIS 10.2 (ESRI, USA) was used to identify the high-risk zones. By using terrain data visualization and reconstruction of topography for the Miyun Reservoir area with the ASTER GDEM datasets it was possible to map shallow regions with the spatial analysis extension, and calculate the surface area of shallow regions with the 3D analysis extension.

\subsection{Optimization algorithm of water level regulation}

The algorithm given in Eqs. (2a) and (2b) was developed to determine the water level in the reservoir which gives the minimum amount of odor-producing cyanobacteria, and thereby the lowest risk for T\&O problems.

$$
\frac{\mathrm{d} \lambda^{*}}{\mathrm{dz}}=10 \% \times \max \left(\frac{\mathrm{d} \lambda}{\mathrm{dz}}\right)
$$

$\lambda=\frac{\mathrm{A}_{\mathrm{r}}(\mathrm{z})}{\mathrm{A}(\mathrm{z})}$
Where $z$ denotes the actual water level, ranging from minimum $\left(z_{\min }\right)$ to maximum elevation $\left(z_{\max }\right)$ according the reservoir management policy; $A_{r}(z)$ denotes the surface area of the high-risk zone when water level is $z, \lambda$ denotes the ratio of high-risk zone surface area $\left(A_{r}(z)\right)$ to the total surface area $(A(z)) ; z^{*}$ and $\lambda^{*}$ denote the optimized water level and corresponding proportion of high-risk zone, respectively. The optimized water level $\left(z^{*}\right)$ was arbitrarily set to where the change in proportion of high-risk surface area $\left(\lambda^{*}\right)$ was $<10 \%$ relative to the change in water level.

\section{Results}

3.1. The effects of water level increases on growth of deep-living cyanobacteria

Planktothrix sp. was proven to be the major MIB-producer in Miyun Reservoir and causing odor problems in recent years (Su et al., 2015); besides, a model has been constructed to estimate the 2-MIB concentration produced by the deep-living Planktothrix. A long term pre-study was performed by collecting samples spread all over Miyun Reservoir during all seasons between 2009 and 2012. The results provided possible clues to the relationship between water depth (the distance between water surface and sediment surface) and Planktothrix sp. biomass (Fig. A.2). The data suggest that Planktothrix sp. prefer to stay in shallow areas, while both the biomass and detection rate (data not shown) of Planktothrix sp. in deep areas were much lower.

As shown in Fig. 2, the relationship between density of Planktothrix sp. cell and water depth (data from specific investigation) was assessed: Cell densities of the 27 studied samples collected at water depth from $1.8 \mathrm{~m}$ to $11.0 \mathrm{~m}$ generally ranged between $1.0 \times$ cells L $^{-1}$ and $4.2 \times$ $10^{6}$ cells $\mathrm{L}^{-1}$. The strong linear correlation between $\log$ (Planktothrix density) and on-site water depth $(\mathrm{R}=0.72, \mathrm{p}<0.01)$ along with sound conceptual reasoning, outlined in (Su et al., 2015), implied that water depth probably is a major factor governing the growth of Planktothrix. This simple linear regression predicts that Planktothrix cell density will exceed $4.0 \times 10^{5}$ cells $\mathrm{L}^{-1}$ in a shallow zone where water depth is $<5.15 \mathrm{~m}$, implying that the risk of suffering T\&O

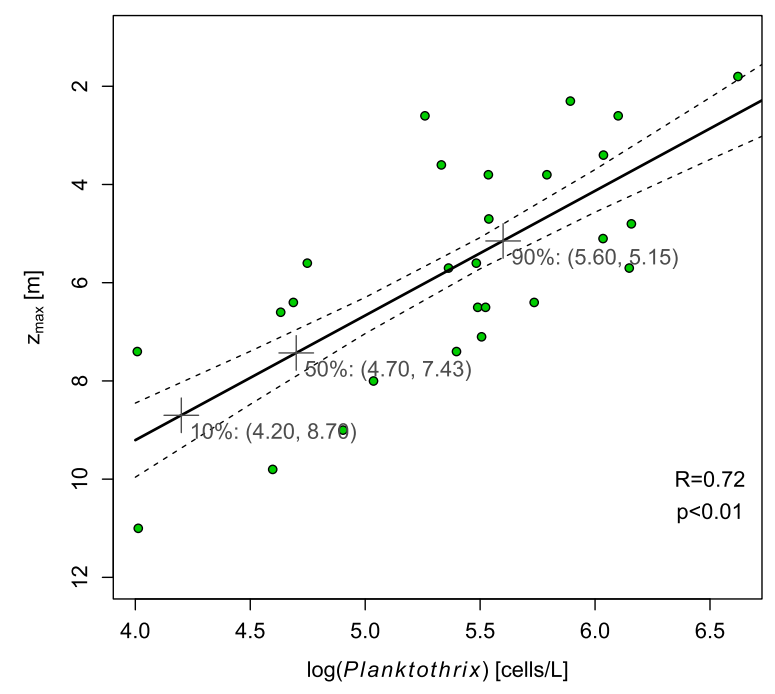

Fig. 2. The correlation between the cell density of Planktothrix sp. and the water depth in Miyun Reservoir. In total of 27 valid samples were collected in shallow regions in late summer (between Sep. 7th and 21st) in 2012; the real line is the log-linear regression between cell density and water depth, while the dashed lines are 95\% confident interval; the three gray crosses denote different risk levels (10\%, 50\% and $90 \%$ ) at which Planktothrix density could cause T\&O problems in Miyun Reservoir, according to the previous study (Su et al., 2015). The risk of suffering T\&O problems (2-MIB concentration exceeding its threshold of $15 \mathrm{ng} \mathrm{L}^{-1}$ ) was $>90 \%$ if Planktothrix cell density exceeded $4.0 \times 10^{5}$ cells $\mathrm{L}^{-1}$. This risk decreased to $50 \%$ and $10 \%$ if the cell density was held below $4.0 \times 10^{4}$ cells $\mathrm{L}^{-1}$ and $1.6 \times 10^{4} 1.6 \times 10^{4}$ cells $\mathrm{L}^{-1}$, respectively. 
problems in such a zone will be higher than $90 \%$. In a zone with water depth higher than $7.43 \mathrm{~m}$ the risk will be decreased to $50 \%$, and at water deeper than $8.70 \mathrm{~m}$ the risk will diminish to $10 \%$.

\subsection{Reducing the risk for $T E O$ problems by regulating water level}

In order to minimize the risk of T\&O problems in Miyun Reservoir it is recommended to control the blooming of odor-producing Planktothrix $\mathrm{sp}$. by regulating the water level. Risk zones are defined as areas with water depth $<5.15 \mathrm{~m}, 7.43 \mathrm{~m}$ or $8.70 \mathrm{~m}$, corresponding to the three risk levels $90 \%, 50 \%$ and $10 \%$. The total area of high-risk zones comprises about $20 \%$ of the reservoir surface when the water level is below $140 \mathrm{~m}$. This proportion declines along with an increase in water level in Miyun Reservoir as shown in Fig. 3. The high-risk area can be reduced by about $2.91 \%(0.61 \%$ to $5.76 \%)$ of surface area for each meter increase in the water level when the water level is lower than $145 \mathrm{~m}$. Optimum water levels to control biomass of Planktothrix sp. at specific risk levels were determined using Eqs. (2a) and (2b): the calculations show that if the water level is maintained below $143.8 \mathrm{~m}$ a.s.l. the risk for the growth of Planktothrix sp. will be very high (90\%). By elevating the water level to $146.3 \mathrm{~m}$ a.s.l. and $147.7 \mathrm{~m}$ a.s.l., the risk will be decreased to $50 \%$ and $10 \%$, respectively, as shown in Fig. 3 . The proportion of highrisk zone surface area is $<5 \%$ at the optimum water level, suggesting that a risk level of $10 \%$ in Eqs. (2a) and (2b) is advisable.

\subsection{Spatial distribution of high-risk zones under different water levels}

Fig. 4 shows the spatial distribution of high-risk zones (acceptable risk level $\leq 50 \%$ ) simulated at four different water levels in the Miyun reservoir (137.0 $\mathrm{m}$ a.s.l., $144.0 \mathrm{~m}$ a.s.l., $151.0 \mathrm{~m}$ a.s.l. and $158.0 \mathrm{~m}$ a.s.l.)(Fig. 4). The high-risk zones mainly comprised the littoral zone around small islands, the north beach and the shallow northeastern regions when the water level was only $137.0 \mathrm{~m}$ a.s.l. Increasing the water level to $144.0 \mathrm{~m}$ a.s.l. led to the islands being submerged beyond $7.0 \mathrm{~m}$ depth, so that they were no longer in the high-risk zone. If water levels were increased to $151.0 \mathrm{~m}$ a.s.l. or $158.0 \mathrm{~m}$ a.s.l. the major high-risk zones only comprised the north shore, as illustrated in Fig. 4. Regarding to the acceptable risk level of $\leq 10 \%$ and $\leq 90 \%$, the high-risk zone

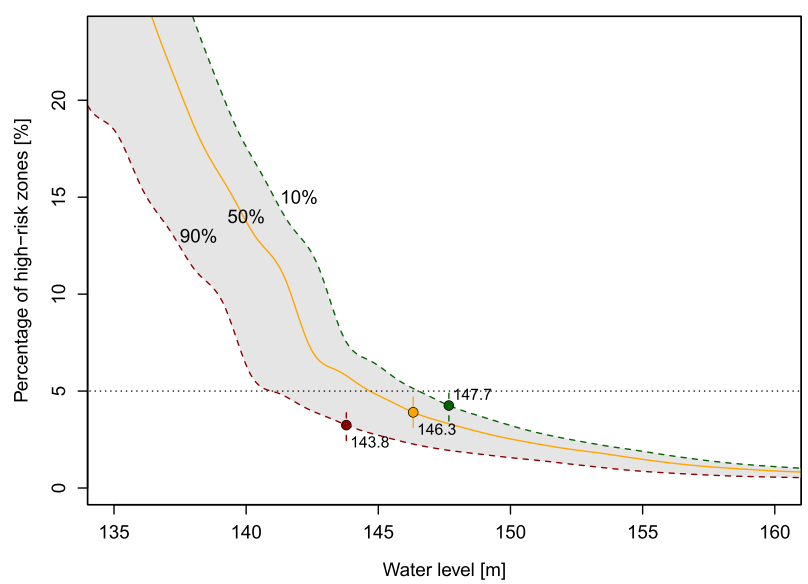

Fig. 3. Optimization of water level regulation to minimize the risk of suffering $T \& 0$ problem in Miyun Reservoir. Y-axis is the proportion $(\lambda)$ of total surface area of highrisk zones $\left(A_{r}(z)\right)$ to total reservoir surface area $(A(z))$, see detail at Eqs. (2a) and $(2 b)$; the real curve denotes the proportion of high-risk zones $(\lambda, y$-axis $)$ at different water level (x-axis), when the accept risk level is 50\%; the long dashed curves denote the proportions of high-risk zones at different water level, when the accept risk levels are $90 \%$ and $10 \%$, respectively; the three cycles denote the optimized water level $\left(z^{*}\right)$ and corresponding proportions of high-risk zone $\left(\lambda^{*}\right)$ at different accept risk levels according to Eqs. (2a) and (2b). dynamics showed similar distributed regularity with $\leq 50 \%$ level, as shown in Fig. A.6 and Fig. A.7.

\subsection{Verification based on historical data}

The water level in Miyun Reservoir has dropped by 21 m, from 154 m a.s.l. in 1999 to $133 \mathrm{~m}$ a.s.l. in 2014, due to continuous over-extraction and drought (Gao et al., 2013; Su et al., 2015). This has led to the circumstance that an extensive area of the reservoir has become shallow waters (north shallow region and northeast shallow region), with a water depth $<11.0 \mathrm{~m}$. The lowering of the water depth to within the habitat range of Planktothrix could thus explain why MIB-producing cyanobacteria have occurred since 2002 in the shallow north region. Fig. 5 demonstrated the dynamic changes in the percentages of highrisk area from the end of the last century to the present based on the model developed in the present study (Fig. 3), the result is consistent with T\&O occurrences recorded in Miyun Reservoir. Increasing the water level, so that the water depth again exceeds $11.0 \mathrm{~m}$ in this section, may therefore be an effective abatement action to curb the growth of Planktothrix.

\subsection{Application to different types of reservoirs}

Miyun Reservoir is a mountain-valley reservoir with several small islands. The size of shallow high-risk zones is therefore decreased with increased water level. Is this the case also in other reservoirs with different bathymetric shapes? Table 1 lists the relationship between water level and area of high-risk zone in reservoirs with different types of bathymetry. A concave shaped reservoir is characterized by a concave functional relationship between the water level $(z)$ and surface area $(S A)$ of the high-risk zone in the interval between the minimum and maximum water level $\left[z_{\min }, z_{\max }\right]$. In this case the recommended water level to minimize the size of high-risk zones is between $z_{\min }$ and the optimized elevation ( $\left.z^{*}\right)$, determined by Eq. (2). In a convex shaped reservoir, such as Miyun Reservoir, the relationship $z=f(S A)$ is described by a convex function. In this case it is recommended to maintain the water level between $z^{*}$ and $z_{\max }$. With combinations of concave and convex forms, as shown in Table 1 , the recommended water level is between $\mathrm{z}_{\min }$ and $\mathrm{z}^{*}$ or between $\mathrm{z}^{* *}$ and $\mathrm{z}_{\max }$ for concave + convex type, and between $\mathrm{z}^{*}$ and $\mathrm{z}^{* *}$ for convex + concave type.

\section{Discussion}

Surface water reservoirs play an essential role as drinking water resources nowadays in the world due to increasing water demand as well as water pollution; however, these reservoirs originally intended for flood control, agricultural irrigation, etc. are likely to be problematic in terms of water quality due to lack of consideration of harmful cyanobacteria growth. The deep-living and benthic cyanobacteria have been widely found to be harmful to water quality as a toxin producer and/or odor producer (Izaguirre et al., 2007; Catherine et al., 2013; Su et al., 2015).

A number of abatement measures have been developed to reduce and control the growth of harmful algal blooms (HABs) in reservoirs. The most commonly used physical, chemical and biological control techniques have recently been summarized by (Newcombe, 2012). The physical controls, including hydrological manipulation and hypolimnetic aeration, are restrained by the volume or depth of the reservoir as well as the expense of power input; surface skimming is also used but cannot be used effectively for deep-living or benthic cyanobacteria. Chemical controls by means of using algaecides, such as copper sulfate, potassium permanganate or chlorine, have the drawbacks that other organisms may also be killed and that the chemicals may remain as contaminants in the water. Other chemical controls, such as coagulation and flocculation, are not able to remove odor 

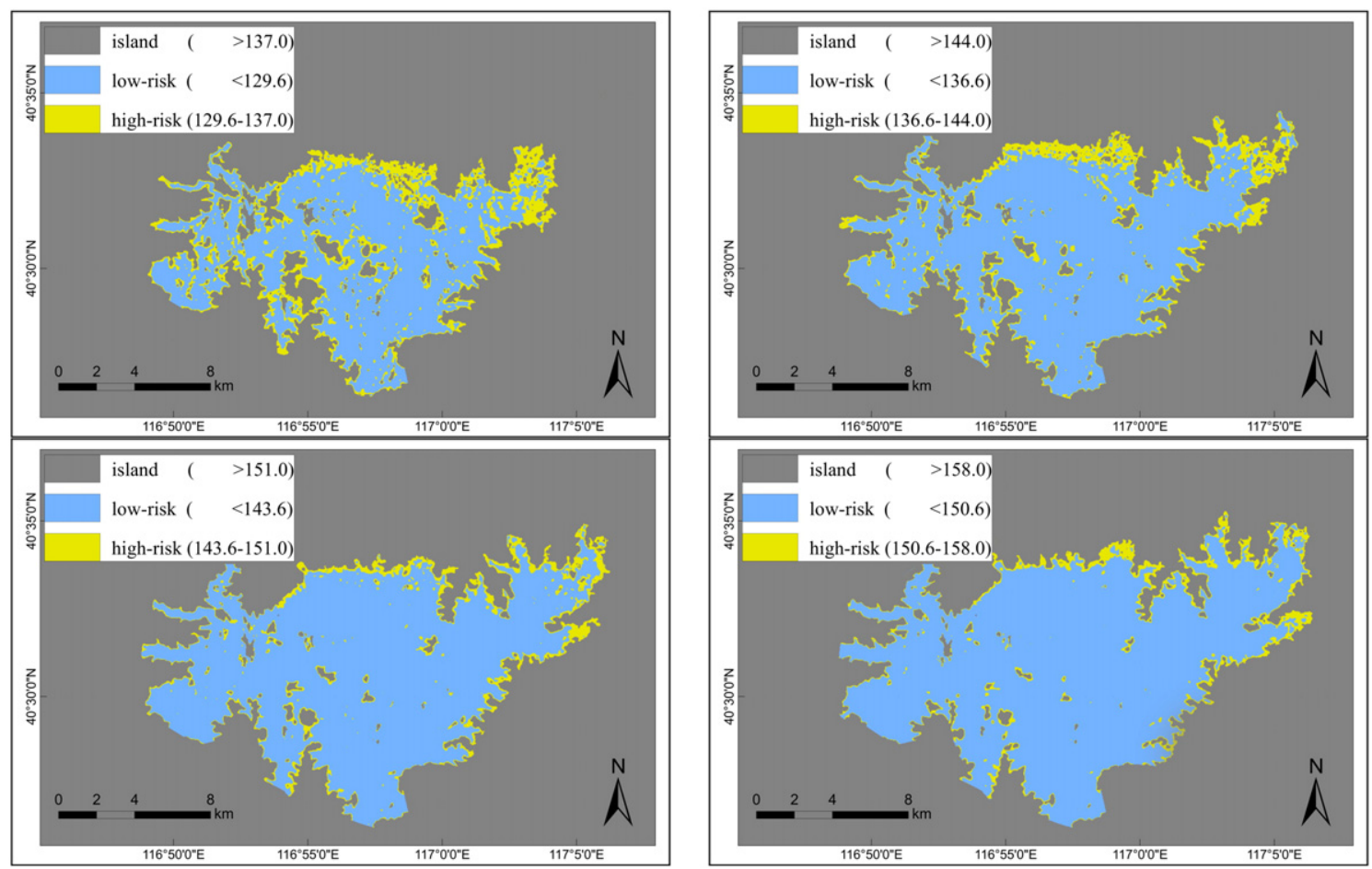

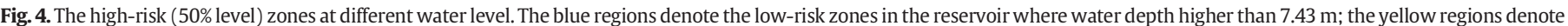

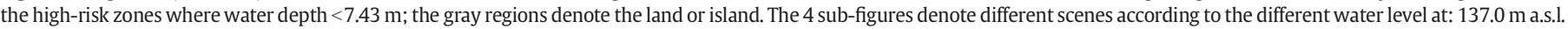
(top-left) $144.0 \mathrm{~m}$ a.s.l. (top-right) $151.0 \mathrm{~m}$ a.s.l. (bottom-left) $158.0 \mathrm{~m}$ a.s.l. (bottom-right), respectively.

compounds, and are additionally subject to depth limitations; e.g. barley straw could inhibit the growth of cyanobacteria by releasing phytotoxic compounds (Everall and Lees, 1997), however it could also color the water. This entails that the use of bio-manipulation to abate algae blooms requires more research in order to fully apprehend grazing behaviors (Peretyatko et al., 2012). Compared to these abatement actions, regulating water level is easier to implement, cheaper, and has no apparent negative effect on water quality and aquatic organisms.

As one of the most important growth factors for cyanobacteria, underwater light availability (Reynolds, 2006) is mainly governed by the distance between the water surface and the layer where the cells stay, together with water transparency. By increasing the water level, the underwater light intensity will be reduced significantly, as shown in Table

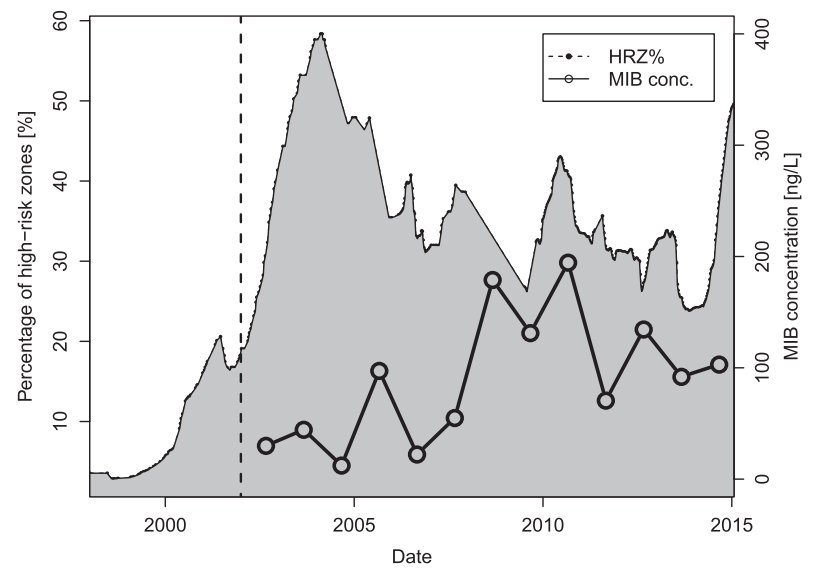

Fig. 5. Dynamic changes of percentages of high-risk area in Miyun Reservoir from 1998 to 2015, according to the model developed in Fig. 3 and recorded water level. No odor event was recorded before 2002, while odor problems repeatedly occurred during the following years, when the high-risk area percentages were much higher than before.
A.1. The descent rate of underwater light intensity only depends on the extinction efficiency of water according to Eq. (A.1). About $2.1 \%$ of light intensity will be reduced by increasing the water level by $10 \mathrm{~cm}$ for water with transparency of $8.0 \mathrm{~m}$ expressed as Secchi depth; while for more turbid water, the reduction rate increases dramatically. According to a water quality investigation in China, the water transparency of reservoirs was mainly distributed in the range of $1.0 \mathrm{~m}$ to $4.0 \mathrm{~m}$ (Herschy, 2012), therefore about $4.2 \%$ to $16 \%$ of light intensity will be reduced for each $10 \mathrm{~cm}$ water level increase, suggesting that this could significantly reduce the risk of Planktothrix bloom. Besides, the risk of taste \& odor problem can be reduced from $90 \%$ to $10 \%$ by increasing the water level for $3.55 \mathrm{~m}$ according to the observations in Miyun Reservoir (Fig. 2), which means about $2.25 \%$ of risk can be reduced for each $10 \mathrm{~cm}$ water level increase in this reservoir when the water depth is in the range of $5.0 \mathrm{~m}$ to $9.0 \mathrm{~m}$. It should be noted that this risk reduction percentage is not linearly related to the water depth. Water depth, water transparency and reservoir bathymetry should be comprehensively considered for each case study. Additionally, in addition to light reduction, water level increase will also reduce the nutrient concentration in the water column since the transportation process will be lowered due to distance increase.

The basic prerequisite for valid implementation of the water level regulation based method is the adjustable interval of water level changes of the reservoir, while most reservoirs are capable of water level regulation within a reasonable interval owing to their inherent function of flood control (Plate, 2002) and agricultural irrigation (Pimentel et al., 2004). The high risk zone can be determined according to the water level and reservoir bathymetry, therefore the basis of the operating rule for water level control is aiming to minimize the area of the risk zone during the high-risk season.

The main habitat for Planktothrix sp. is shallow water bodies or littoral zones where the water depth is $<11.0 \mathrm{~m}$ (Chu et al., 2007; Halstvedt et al., 2007; Jähnichen et al., 2011; Su et al., 2015). Raising the water level in Miyun Reservoir during the high-risk season (late summer) for Planktothrix bloom is thus a possible solution to control its growth 
Table 1

Optimization of water level management to minimize cyanobacterial bloom for different reservoir types.

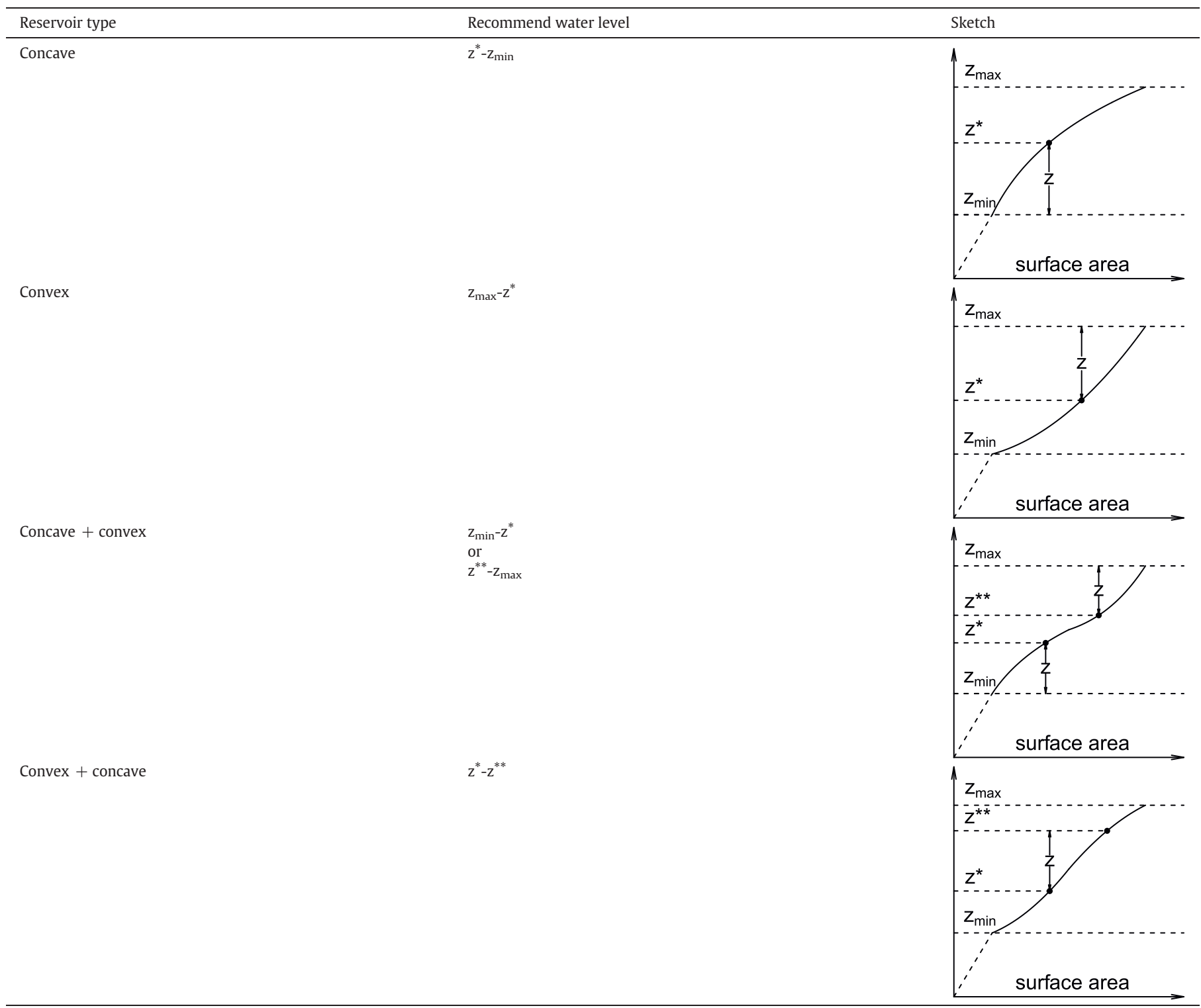

and thereby reduce the risk of T\&O problems. Moreover, the result suggests that the $\log$ (Planktothrix density) decrease linearly with water depth as shown in Fig. 2.

To the best of our knowledge, this is the first study to assess the possibility of controlling the growth of cyanobacteria in shallow reservoirs by regulating the water level; it thus can be used as a supplement to traditional methods. In addition, this study suggests that consideration of reservoir bathymetry and shape so as to minimize the shallow regions is necessary and essential regarding the potential for cyanobacterial bloom during reservoir design and construction.

\section{Conclusions}

The potential effect of regulating the water level in Miyun Reservoir in order to reduce the risk of T\&O problems caused by Planktothrix sp. was assessed by evaluating the changes in the area of high-risk zones. Based on this study the following conclusions were drawn:

- Water level regulation is a feasible abatement action to control deepliving or benthic cyanobacterial bloom in reservoirs.
- The optimized water level differs for different types of reservoirs (Table 1).

- The risk of suffering T\&O problems can be significantly reduced (to $<10 \%$ ) if the water level is increased to $147.7 \mathrm{~m}$ a.s.l. in Miyun Reservoir.

\section{Acknowledgments}

This work was financially supported by the National Natural Science Foundation of China ( 51508549 and 5120283), the Funds for Major Science and Technology Program for Water Pollution Control and Treatment (2015ZX07406001) as well as by bilateral support from the Norges Forskningsråd (209687/E40).

\section{Appendix A. Supplementary data}

Supplementary data to this article can be found online at http://dx. doi.org/10.1016/j.scitotenv.2016.08.134. 


\section{References}

Anonymous, 2014. South-to-north water diversion project, China. http://www.watertechnology.net/projects/south_north/.

AWWA, A.W.W.A., 2010. Algae: Source to Treatment. American Water Works Association. Bellinger, E.G., 1974. A Key to the Identification of the More Common Algae Found in British Freshwaters. Water Treat. Examination 23, pp. 76-131.

Catherine, Q., Susanna, W., Isidora, E.-S., Mark, H., Aurélie, V., Jean-François, H., 2013. A review of current knowledge on toxic benthic freshwater cyanobacteria - ecology, toxin production and risk management. Water Res. 47 (15), 5464-5479.

Chu, Z., Jin, X., Iwami, N., Inamori, Y., 2007. The Effect of Temperature on Growth Characteristics and Competitions of Microcystis aeruginosa and Oscillatoria mougeotii in a Shallow, Eutrophic Lake Simulator System. In: Qin, B., Liu, Z., Havens, K. (Eds.), Eutrophication of Shallow Lakes with Special Reference to Lake Taihu, ChinaVol. 194 of Developments in Hydrobiology. Springer Netherlands, pp. 217-223 http://dx.doi.org/ 10.1007/978-1-4020-6158-5_24.

DAAC, L., 2014. Routine aster global digital elevation model. https://pdaac.usgs.gov/node/ 1079.

Dokulil, M., Teubner, K., 2012. Deep living Planktothrix rubescens modulated by environmental constraints and climate forcing. Hydrobiologia 698 (1), 29-46.

Everall, N., Lees, D., 1997. The identification and significance of chemicals released from decomposing barley straw during reservoir algal control. Water Res. 31 (3), 614-620.

Gao, X., Hao, L., Luo, Y., 2013. Problems and strategies of miyun reservoir in the south-tonorth water diversion project. Beijing Water 2013 (6), 56-59.

Halstvedt, C.B., Rohrlack, T., Andersen, T., Skulberg, O., Edvardsen, B., 2007. Seasonal dynamics and depth distribution of Planktothrix spp. in lake steinsfjorden (Norway) related to environmental factors. J. Plankton Res. 29 (5), 471-482.

Hasle, G., 1978. The Inverted Microscope Method. Phytoplankton Manual. UNESCO, Paris, pp. 88-96.

Herschy, R.W., 2012. World Lake Database: International Lake Environment Committee Foundation (Ilec). In: Bengtsson, L., Herschy, R.W., Fairbridge, R.W. (Eds.), Encyclopedia of Lakes and Reservoirs. Springer Netherlands, Dordrecht, pp. 920-921 http://dx. doi.org/10.1007/978-1-4020-4410-6_188.

Izaguirre, G., 1992. A copper-tolerant Phormidium species from Lake Mathews, California, that produces 2-methylisoborneol and geosmin. Water Sci. Technol. 25 (2), 217-223.

Izaguirre, G., Taylor, W.D., 1998. A Pseudanabaena species from castaic lake, California, that produces 2-methylisoborneol. Water Res. 32 (5), 1673-1677.

Izaguirre, G., Taylor, W., 2007. Geosmin and mib events in a new reservoir in southern California. Water Sci. Technol. 55 (5), 9-14.

Izaguirre, G., Jungblut, A.-D., Neilan, B.A., 2007. Be nthic cyanobacteria (oscillatoriaceae) that produce microcystin-lr, isolated from four reservoirs in southern California. Water Res. 41 (2), 492-498.

Jähnichen, S., Jäschke, K., Wieland, F., Packroff, G., Benndorf, J., 2011. Sp atio-temporal distribution of cell-bound and dissolved geosmin in wahnbach reservoir: causes and potential odour nuisances in raw water. Water Res. 45 (16), 4973-4982.
Komárek, J., Anagnostidis, K., 1998. Cyanoprokaryota 1 vol. 19(1). DEU.

Kurek, W., Ostfeld, A., 2013. Multi-objective optimization of water quality, pumps operation, and storage sizing of water distribution systems. J. Environ. Manage. 115, 189-197.

Ling, H.U., Tyler, P.A., 2000. Australian Freshwater Algae (Exclusive of Diatoms). Vol. 5. J. Cramer in Der Gebrueder Borntraeger Verlagsbuchhandlung, Antarctic Division, Channel Highway, Kingston, TAS, 7050, USA (http://www.schweizerbart.de// publications/detail/isbn/9 783443600327/Australian_Freshwater_Algae_exclusive_ of_diatoms, 04).

Newcombe, G., 2012. International Guidance Manual for the Management of Toxic Cyanobacteria. IWA Publishing.

Peretyatko, A., Teissier, S., De Backer, S., Triest, L., 2012. Biomanipulation of hypereutrophic ponds: when it works and why it fails. Environ. Monit. Assess. 184 (3), 1517-1531.

Pimentel, D, Berger, B, Filiberto, D, Newton, M. Wolfe, B, Karabinakis, E., Clark, S, Poon, E., Abbett, E., Nandagopal, S., 2004. Water resources: agricultural and environmental issues. Bioscience 54 (10), 909-918.

Plate, E.J., 2002. Flood risk and flood management. J. Hydrol. 267 (1â̧̦̆̊2), 2-11 (advances in Flood Research).

Prescott, G., 1951. Algae of the Western Great Lakes Area: Exclusive of Desmids and Diatoms. Cranbrook Institute of Science.

Reynolds, C.S., 2006. Ecology of Phytoplankton. Cambridge University Press, Cambridge. Scott, J.T., Marcarelli, A.M., 2012. Cyanobacteria in Freshwater Benthic Environments. In: Whitton, B.A. (Ed.), Ecology of Cyanobacteria II. Springer Netherlands, pp. 271-289 http://dx.doi.org/10.1007/978-94-007-3855-3_9.

Sherr, E.B., Sherr, B.F., 1993. Preservation and Storage of Samples for Enumeration of Heterotrophic Protists. Handbook of Methods in Aquatic Microbial Ecology. Lewis Publishers, Boca Raton, pp. 207-212.

SNWDP, C. o. t. S. C., 2014. South-to-north water diversion project, China. http://www. nsbd.gov.cn/zx/english/mrp.htm.

Su, M., An, W., Yu, J., Pan, S., Yang, M., 2014. Importance of underwater light field in selecting phytoplankton morphology in a eutrophic reservoir. Hydrobiologia 724 (1), 203-216.

Su, M., Yu, J., Zhang, J., Chen, H., An, W., Vogt, R.D., Andersen, T., Jia, D., Wang, J., Yang, M., 2015. Mib-producing cyanobacteria (Planktothrix sp.) in a drinking water reservoir: distribution and odor producing potential. Water Res. 68 (0), 444-453.

Sugiura, N., Iwami, N., Inamori, Y., Nishimura, O., Sudo, R., 1998. Significance of attached cyanobacteria relevant to the occurrence of musty odor in Lake Kasumigaura. Water Res. 32 (12), 3549-3554.

Westerhoff, P., Rodriguez-Hernandez, M., Baker, L., Sommerfeld, M., 2005. Seasonal occurrence and degradation of 2-methylisoborneol in water supply reservoirs. Water Res. 39 (20), 4899-4912.

Yang, M., Yu, J., Li, Z., Guo, Z., Burch, M., Lin, T.-F., 2008. Taihu lake not to blame for wuxi's woes. Science 319 (5860), 158 